\title{
Television Tip-Over Related Head Injuries: A Particular Type of Child Neglect
}

\author{
Burak EREN ${ }^{1}$, Abdurrahim TAS², Feyza KARAGOZ GUZEY¹, Ilker GULEC ${ }^{1}$, Azmi TUFAN ${ }^{1}$, Murat KARACAN ${ }^{1}$ \\ ${ }^{1}$ Health Sciences University, Bagcilar Training and Research Hospital, Department of Neurosurgery, Istanbul, Turkey \\ ${ }^{2}$ Health Sciences University, Gazi Yasargil Training and Research Hospital, Department of Neurosurgery, Diyarbakır, Turkey \\ This study has been presented orally at the $16^{\text {th }}$ WFNS World Congress of Neurosurgery between 20 and 25 August 2017 at Istanbul, Turkey.
}

Corresponding author: Burak EREN drburakeren@hotmail.com

\section{ABSTRACT}

AIM: To identify, report, and raise awareness of the risk factors for television (TV) tip-over.

MATERIAL and METHODS: In total, 86 children who were brought to the emergency service and hospitalized at the neurosurgery clinic because of TV tip-over-related head trauma between August 2011 and August 2016 were included in the study.

RESULTS: The 86 patients consisted of 47 males and 39 females. The mean age was $38.8 \pm 19.5$ (9-102) months. Low education level of the mother was a risk factor for this type of accident $(p=0.009)$. In all the patients, injuries were caused by the tip-over of a cathode ray tube (CRT) TV. In 66 patients (77\%), only the TV tipped over onto the child, whereas in 20 cases (23\%), the TV tipped over with the TV stand. The TVs were not fixed to the stand or the wall in any of the homes. According to computerized tomography findings, 12 patients (13.9\%) had intracranial hemorrhage and 19 patients (22\%) had skull fractures. Five patients underwent neurosurgical intervention. Eighty-four patients (97.6\%) were discharged with a GCS level of 15 . One patient was discharged with a GCS level of $9 / 15$ with a tracheostomy and nasogastric tube. One patient died.

CONCLUSION: TV tip-over causes physical injury that may result in serious neurological damage and even death. It is becoming more common and may be prevented by taking simple precautions.

KEYWORDS: Television tip-over, Television falls, Head trauma, Child trauma, Pediatric trauma

\section{INTRODUCTION}

$\mathrm{T}$ Television (TV) tip-overs may cause serious injury or death in young children. In the young children age group, $84 \%$ of major traumas occur at home. Three out of four of these traumas occur when an adult is not present (5).

The most common cause of furniture-related accidents is TV tip-over $(42 \%-48 \%)(4,11)$. TV tipover injuries in children are becoming more frequently reported as TVs have become larger and more affordable and common. With larger TV screens and younger children, the severity of injury tends to increase. Head trauma occurs in approximately $70 \%$ of the cases (8). The majority of the parents of children suffering a TV tip-over-related injury are unaware that this kind of event poses a significant risk for their children (19).

The purpose of this study was to identify, report, and raise awareness of the risk factors for TV tip-over.

\section{MATERIAL and METHODS}

In total, 86 children who were brought to the emergency department and hospitalized in the neurosurgery clinic of our hospital because of TV tip-over-related head trauma between August 2011 and August 2016 were included in the study.

$\begin{array}{llll}\text { Burak EREN } & \text { (1) : }: 0000-0001-5554-2585 & \text { Ilker GULEC } & \text { (1) : 0000-0003-4207-238X } \\ \text { Abdurrahim TAS } & \text { (D) : 0000-0001-5786-9063 } & \text { Azmi TUFAN } & \text { (1) : 0000-0001-9042-8542 } \\ \text { Feyza KARAGOZ GUZEY } & \text { (1) : :0000-0002-4260-9821 } & \text { Murat KARACAN } & \text { (1) : 0000-0003-3718-9938 }\end{array}$


Patient's age, sex, family characteristics, clinical presentation on arrival and details about case management including surgical intervention, duration of hospital stay and results were prospectively obtained from case records. In addition, information on how the accident occurred, TV shape, size, height of the TV and type of TV stand was also obtained.

\section{Statistical Analysis}

In this study, statistical analyses were carried out using the Number Cruncher Statistical System 2007 Statistical Software (Utah, USA). Descriptive statistical methods (mean and standard deviation) were used to analyze the data. In addition, unidirectional analysis of variance for comparisons of normally distributed variables, Kruskal-Wallis test for comparisons of non-normally distributed variables, Dunn's multicomparative test for subgroup comparisons, and $x^{2}$ test for comparisons of qualitative data were used. The outcomes were evaluated at a significance level of $p<0.05$.

\section{RESULTS}

In total, 86 pediatric patients were hospitalized because of TV tip-over-related head trauma in our neurosurgery clinic over a period of 5 years. Of these 86 patients, 47 were males and 39 were females. The mean age was $38.8 \pm 19.5$ (9-102) months. All incidents took place in the child's home. All patients exhibited similar family characteristics. None of the mothers were employed, and all mothers reported that they were at home at the time of the incident. In contrast, only $23.2 \%$ of fathers were at home at the time of the incident. It was found that low education level of the mother was a risk factor for this type of domestic accident $(p=0.009)$. However, there was no correlation of the accident with the education level of the father $(\mathrm{p}=0.67)$. Seventy-four patients $(86 \%)$ had siblings, and 36 patients $(41.8 \%)$ had more than one sibling. The demographic characteristics of the patients are shown in Table I.

In all the patients, injuries were caused by the tip-over of a cathode ray tube (CRT) TV. Approximately $74.4 \%$ of the families had flat-panel (FP) TVs, such as liquid crystal display, light-emitting diodes, and plasma TVs. Average screen size of the TV was $27.7 \pm 3(20-32)$ inches. A variety of supportive structures were involved in the accident, but dressers were the most common. TVs were placed on stands that were either stable $(70.9 \%)$ or had wheels $(29.1 \%)$. The TVs were not fixed to the stand or the wall in any of the patient's home. In 66 patients (77\%), only the TV tipped over onto the child, whereas in 20 cases $(23 \%)$, the TV tipped over with the dresser. The average height of the fall was 1.06 meters (0.51.5). It was reported that in 83 cases, the child had him-/ herself tipped over the TV, whereas the patient's sibling had tipped over the TV in the remaining three cases. The injured child was unattended in $65 \%$ of the cases.

The mean Glasgow Coma Scale (GCS) score at admission was $13.9 \pm 1.1$ (5-15). According to computerized tomography (CT) findings, 12 patients (13.9\%) had intracranial hemorrhage and 19 patients (22\%) had skull fractures. Six patients displayed otorrhea or rhinorrhea, and 17 patients (19.7\%) had other injuries as well. The most common injuries were clavicular fracture in 9 patients and humeral fracture in five. Three patients had facial paralysis, one patient had pneumothorax, one suffered liver laceration, and one had a tibial fracture. The coexistence of intracranial hemorrhage and trauma to other systems was significantly higher $(p<0.001)$ (Table II).

Table I: Demographic Characteristics of the Cases

\begin{tabular}{|c|c|c|c|c|}
\hline & $0-24$ months $(n=20)$ & $25-48$ months $(n=38)$ & >49 months $(n=28)$ & $\mathbf{p}$ \\
\hline Variable & n (\%) & n (\%) & n (\%) & \\
\hline Male & $14(70)$ & $20(52.6)$ & $13(46.4)$ & \\
\hline Females & $6(30)$ & $18(47.4)$ & $15(53.6)$ & \\
\hline Primary school & $11(55)$ & $33(86.8)$ & $23(82.1)$ & \\
\hline Secondary school & $7(35)$ & $4(10.5)$ & $1(3.6)$ & \\
\hline High school / University & $2(10)$ & $1(2.7)$ & $4(14.3)$ & \\
\hline Father's educational status & & & & 0.67 \\
\hline \multirow[t]{2}{*}{ High school / University } & $5(25)$ & $6(15.8)$ & $5(17.9)$ & \\
\hline & \multicolumn{3}{|c|}{ Mean \pm Standart Deviation } & \\
\hline Siblings & $1.15 \pm 0.93$ & $1.66 \pm 1.55$ & $1.82 \pm 1.34$ & 0.22 \\
\hline
\end{tabular}

Significant $p$ values were shown with bold characters. $(n=$ Number). 
Five patients underwent surgery (Table III). The patients were hospitalized for a mean period of $2.1 \pm 5.6(1-46)$ days. Twelve patients with poor clinical status were hospitalized for $15.2 \pm$ 35.6 (1-128) days in the intensive care unit (ICU). Eighty-four patients (97.6\%) were discharged as with a GCS score of 15 . One patient was discharged with a GCS score of $9 / 15$ with a tracheostomy and nasogastric tube. One patient died.

\section{DISCUSSION}

TV tip-over accidents are mostly reported in young children, and they generally cause head trauma (13). Reports from a large series found that $0.4 \%-0.5 \%$ of all head traumas are caused by TV tip-overs $(14,15)$. Young children have thin skulls, and their large head-to-body ratio predisposes them to head injuries (22). The majority of these traumas take place in the child's own home and when an adult is not present (7). Mean age, gender, fraction of total injuries presenting in the head, surgical intervention, length of hospital stay and mortality rate from international studies are presented in Table IV. The most frequently reported injuries are those to the head and neck.

Lichenstein et al. reported a mean age of 3.1 months (14), similar to our findings. Another study reported that $61 \%$ of the patients were boys (9). In our study, we found this percentage to be $54.6 \%$ and concluded that sex is not a risk

Table II: Evaluation of Cases According to CT Findings

\begin{tabular}{|c|c|c|c|c|c|c|c|c|c|c|c|}
\hline & & & \multicolumn{2}{|c|}{$\begin{array}{l}\text { Normall } \\
(n=55)\end{array}$} & \multicolumn{2}{|c|}{$\begin{array}{l}\text { Skull fracture } \\
\qquad(n=13)\end{array}$} & \multicolumn{2}{|c|}{$\begin{array}{c}\text { Skull base } \\
\text { fracture+CSF leak } \\
(n=6)\end{array}$} & \multicolumn{2}{|c|}{$\begin{array}{l}\text { Hemorrhage } \\
\qquad(n=12)\end{array}$} & $\mathbf{p}$ \\
\hline \multicolumn{3}{|l|}{ Age (Months) } & \multicolumn{2}{|c|}{$39.8 \pm 19.3$} & \multicolumn{2}{|c|}{$33.2 \pm 14$} & \multicolumn{2}{|c|}{$41 \pm 35.1$} & \multicolumn{2}{|c|}{$39.7 \pm 17$} & 0.736 \\
\hline \multirow{2}{*}{ Gender } & \multicolumn{2}{|c|}{ Male } & 28 & $(50.9 \%)$ & 8 & $(61.5 \%)$ & 3 & $(50 \%)$ & 8 & $(66.7 \%)$ & \multirow{2}{*}{0.727} \\
\hline & \multicolumn{2}{|c|}{ Female } & 27 & $(49.1 \%)$ & 5 & $(38.5 \%)$ & 3 & $(50 \%)$ & 4 & $(33.3 \%)$ & \\
\hline \multirow{2}{*}{ GCS } & \multicolumn{2}{|c|}{ Initial } & \multicolumn{2}{|c|}{15} & \multicolumn{2}{|c|}{$14.1 \pm 0.9$} & \multicolumn{2}{|c|}{$13.3 \pm 1.3$} & \multicolumn{2}{|c|}{$9.4 \pm 3.1$} & 0.0001 \\
\hline & \multicolumn{2}{|c|}{ At discharge } & \multicolumn{2}{|c|}{15} & \multicolumn{2}{|c|}{15} & \multicolumn{2}{|c|}{15} & \multicolumn{2}{|c|}{$13.5 \pm 1.5$} & 0.009 \\
\hline \multirow[t]{3}{*}{ TV Size (cm) } & \multicolumn{2}{|c|}{$51-69$} & 11 & $(20 \%)$ & 1 & $(7.7 \%)$ & 2 & $(33.3 \%)$ & 0 & $(0 \%)$ & \multirow[t]{3}{*}{0.178} \\
\hline & $70-79$ & 35 & $(63.6 \%)$ & 10 & $(77 \%)$ & 4 & $(66.7 \%)$ & 12 & $(100 \%)$ & & \\
\hline & $>80$ & 9 & $(16.4 \%)$ & 2 & $(15.3 \%)$ & 0 & $(0 \%)$ & 0 & $(0 \%)$ & & \\
\hline \multicolumn{3}{|c|}{ Other system trauma } & 5 & $(9.1 \%)$ & 2 & $(15.3 \%)$ & 3 & $(50 \%)$ & 7 & $(58.3 \%)$ & 0.0001 \\
\hline \multirow{2}{*}{ TV Stand } & \multicolumn{2}{|c|}{ Wheeled } & 19 & $(34.5 \%)$ & 2 & $(15.4 \%)$ & 1 & $(16.7 \%)$ & 3 & $(25 \%)$ & \multirow{2}{*}{-0.471} \\
\hline & \multicolumn{2}{|c|}{ Without wheels } & 36 & (65.5\%) & 11 & (84.6\%) & 5 & (83.3\%) & 9 & (75\%) & \\
\hline
\end{tabular}

Age, Initial GCS and Discharged GCS score data are presented with means \pm standard deviations and others are presented with \%. Significant $p$ values were shown with bold characters. (n: Number, CSF: Cerebrospinal fluid, GCS: Glasgow Coma Scale).

Table III: Characteristics of Surgically Trested Patients

\begin{tabular}{|c|c|c|c|c|c|c|c|c|}
\hline $\mathbf{n}$ & $\begin{array}{c}\text { Age } \\
\text { (months) }\end{array}$ & Gender & CT findings & Other trauma & $\begin{array}{l}\text { Initial GCS } \\
\text { score }\end{array}$ & $\begin{array}{l}\text { Additional } \\
\text { surgery }\end{array}$ & $\begin{array}{l}\text { ICU stay } \\
\text { (day) }\end{array}$ & $\begin{array}{c}\text { Outcome } \\
\text { (Final GCS } \\
\text { score) }\end{array}$ \\
\hline 1 & 29 & M & $\begin{array}{c}\text { Depressed skull fracture }+ \\
\text { Pneumocephalus }\end{array}$ & $\begin{array}{l}\text { Nasal fracture }+ \\
\text { Clavicula fracture }\end{array}$ & $15 / 15$ & None & 0 & 15 \\
\hline 2 & 60 & $\mathrm{~F}$ & Frontal SDH & Humerus fracture & $9 / 15$ & None & 4 & 15 \\
\hline 3 & 27 & M & Frontal EDH + tSAH & $\begin{array}{l}P x+\text { Clavicula } \\
\text { fracture }\end{array}$ & $5 / 15$ & Chest tube & 9 & Died \\
\hline 4 & 60 & M & $\begin{array}{l}\text { Intraorbital hematoma + } \\
\text { Skull base fracture }\end{array}$ & Facial paralysis & $12 / 15$ & Duraplasty & 1 & 15 \\
\hline 5 & 25 & M & $\begin{array}{c}\text { Posterior fossa EDH + } \\
\text { tSAH }\end{array}$ & $\begin{array}{l}\text { Liver laceration }+ \\
\text { Clavicula fracture }\end{array}$ & $5 / 15$ & V-P shunt & 128 & $9 / 15$ \\
\hline
\end{tabular}

$\boldsymbol{n}=$ Number, $\mathbf{C T}=$ Computerized tomography, ICU=Intensive care unit, GCS= Glasgow Coma Scale, $\mathbf{B}=$ Boy, $\mathbf{G}=$ Girl, $\boldsymbol{f r}=$ Fracture, $\mathbf{E D H}=$ Epidural hematoma, $\mathbf{S} \boldsymbol{D H}=$ Acute subdural hematoma, $\mathbf{S} \boldsymbol{A} \boldsymbol{H}=$ Traumatic subarachnoid hemorrhage, $\boldsymbol{P} \mathbf{x}=$ Pneumothorax, $\boldsymbol{V}$ - $\boldsymbol{P}=$ Ventriculoperitoneal. 


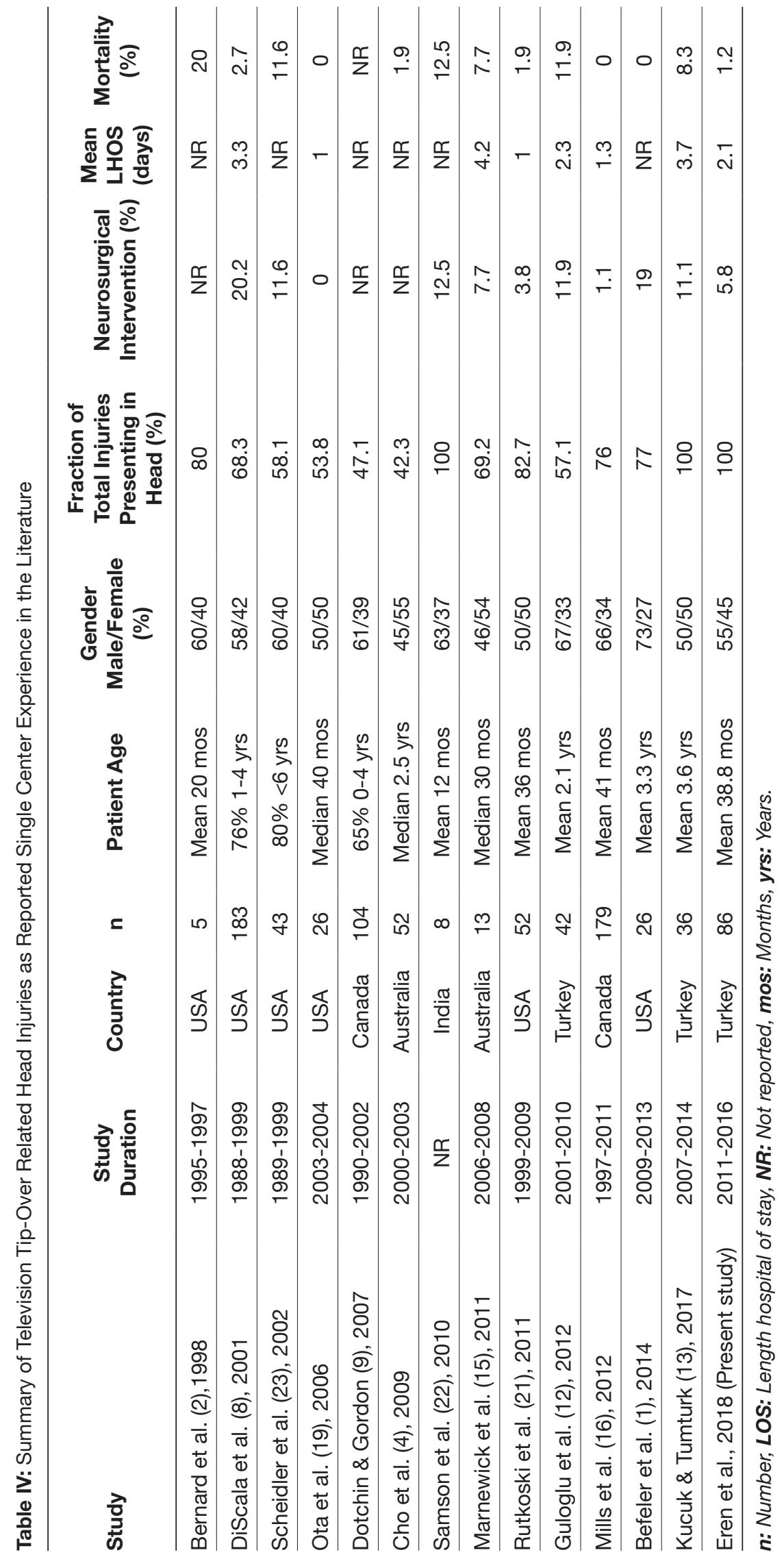


factor for TV tip-over. However, according to Murray et al. (18), boys are at a higher risk of injury than girls. It has been reported that toddlers are susceptible to injury and that there is a relationship between low education level of the family and injuries to children (10). In our study, we found the low education level of the mother to be related to increased risk of TV tip-over, but no relationship with the education level of the father was found.

An average young child watches TV for approximately $4 \mathrm{~h}$ per day. Large screen TVs present in most houses weigh between 36 and $80 \mathrm{~kg}$. As the center of gravity of CRT TVs lies toward the front of the appliance, the TV may easily tip over if it is not on a suitable and durable TV stand (8). We found that all the traumas in our patients resulted from CRT TV tip-over. Mills et al. reported that the preferred choice of TV for $75 \%$ of families was FP TVs (16), which were generally fixed on a TV stand or wall. CRT TVs that they had previously used tended to be on unsuitable stands in other rooms. Since the advent of FP TVs, these devices have become progressively lighter and thinner. Thus, they are believed to greatly reduce the risk of tipovers (7). Rutkoski et al. reported that the most common TV size implicated in these injuries was 27 inches (21), and there was no statistically significant relationship between the TV size and the severity of the injury. We observed the same results in our study. However, De Roo et al. reported that two-thirds of these injuries occurred because of screen sizes of $\leq 26$ inches (6).

When a child pushes a TV, it most likely falls on the head and neck of the child because of the child's height in relation to the height of the TV (17). The TV is elevated off the ground 0.5-1.5 meters (5). Scheidler et al. reported that the average height of the fall was 1.12 meters (23), as in our cases. Dressers and other furniture not designed to support televisions were commonly involved in the TV-toppling injury (5). While most cases are not fatal, serious injuries may be inflicted. Soft tissue injuries and lacerations predominate, accounting for $36 \%$ of the injuries reported (6). This percentage was found to be $64 \%$ in our study. Ota et al. reported that head trauma frequently occurs with injuries to the extremities (19). Upper extremity injuries were more common in our study. However, in contrast to our study, this previous study found lower extremity injuries to occur more frequently. It has also been reported that the average GCS score on admission was 12 (1). Our patients demonstrated a mean GCS score of 13.9. Befeler et al. reported that neurosurgery was attempted in $19 \%$ of hospitalized patients, all of whom had CRT TV tip-over injuries (1). They also reported that the average length of ICU stay was 4.8 days. In our study, neurosurgery was attempted in $5.8 \%$ of patients, and 12 patients had an average ICU follow-up period of 15.2 days.

Mortality rates in large case studies have been reported to be $2 \%-11.9 \%$, which are similar to those for traffic accidents $(3,8,12)$. Head trauma is responsible for $96 \%$ of deaths $(2,5)$. Platt et al. reported death of three patients in their study (ages; 11, 21, and 36 month), all of whom died because of head trauma after TV tip-over, and distinguished them from abusive head trauma (20). These three children were all injured by CRT TVs. One of the patients in our study died; this child had a GCS of 5/15 on arrival by ambulance to our hospital. Following cardiac arrest, resuscitation was performed by the emergency department. A thoracostomy tube was inserted because of bilateral pneumothorax. Cranial CT revealed epidural hemorrhage, subarachnoid hemorrhage, and diffuse edema. Epidural hemorrhage was emergently drained. The patient was followed up in postoperative ICU but died on the ninth postoperative day.

This form of trauma, which can result in such serious consequences, is actually easily avoidable. The main problem is a lack of awareness by parents that such a trauma can occur and to take necessary precautions. A study verified that $85 \%$ of mothers and fathers whose children suffered TV tipover injuries had been unaware of this risk (23). We observed that none of our patients had a TV fixed to a stand or wall. Therefore, we believe that this type of trauma represents child neglect.

In order to prevent this, training for families with young children should be provided before the toddler period. Training by TV and TV stand vendors would also be effective in reducing such injuries. CRT TVs should be placed in a rectangular wooden furniture with 4 fixed legs and the center of gravity should be designed to be located in the center of the furniture. FPTVs should be fixed to the wall or stand. Also, the height of the TVs should be at least 1.5 meters. Cables should be hidden as children can not reach them. In addition, manufacturers should be asked to add warnings to their brochures and to produce more stable devices.

\section{CONCLUSION}

TV tip-over causes physical injury that may result in serious neurological damage and death and is becoming more common. As it may be prevented by taking simple precautions, it can be considered as a particular form of child neglect. In addition to improving the designs of TV sets and TV stands, strategies should be implemented to educate the public.

\section{REFERENCES}

1. Befeler AR, Daniels DJ, Helms SA, Klimo P Jr, Boop F: Head injuries following television-related accidents in the pediatric population. J Neurosurg Pediatr 14(4):414-417, 2014

2. Bernard PA, Johnston C, Curtis SE, King WD: Toppled television sets cause significant pediatric morbidity and mortality. Pediatrics 102(3): E32, 1998

3. Bol O, Cebicci H, Koyuncu S, Sarlı B, Gunay N: A hidden household danger: Television. Ulus Travma Acil Cerrahi Derg 22(3): 265-268, 2016

4. Cho JH, Adams S, Holland AJA: Furniture injuries in children. J Paed Child Health 45: 505-508,2009

5. Cusimano MD, Parker N: Toppled television sets and head injuries in the pediatric population: A framework for prevention. J Neurosurg Pediatr 17:3-12, 2016

6. De Roo AC, Chounthirath T, Smith GA: Television-related injuries to children in the United States, 1990-2011. Pediatrics 132(2): 267-274, 2013 
7. Deisch C, Quinton R, Gruszecki C: Craniocerebral trauma inflicted by television falls. J Forensic Sci 56: 1049-1053, 2011

8. DiScala C, Barthel M, Sege R: Outcomes from television sets toppling onto toddlers. Arch Pediatr Adolesc Med 155:145148,2001

9. Dotchin SA, Gordon KE: The terrible truth about toppling televisions. Paediatr Child Health 12(3): 221-224, 2007

10. Gaines J, Schwebel DC: Recognition of home injury risks by novice parents of toddlers. Accid Anal Prev 41(5):1070-1074, 2009

11. Gottesman BL, McKenzie LB, Conner KA, Smith GA: Injuries from furniture tip-overs among children and adolescents in the United States, 1990-2007. Clin Pediatr 48: 851-858, 2009

12. Guloglu R, Sarıcı IS, Bademler S, Emirikci S, İssever H, Yanar $\mathrm{H}$, Ertekin C: Falling television related child injuries in Turkey: 10-year experience. Ulus Travma Acil Cerrahi Derg 18: 61-64, 2012

13. Kucuk A, Tumturk A: Television tip overs and head traumas in childhood: Results of 36 children from a reference center in Central Anatolia, Turkey. Turk Neurosurg 27(6):931-934, 2017

14. Lichenstein R, Monroe D, Quayle KS, Miskin M, Cooper A, Gerardi MJ, Callahan JM, Dayan PS, Holmes JF, Kuppermann $\mathrm{N}$ : Television-related head injuries in children a secondary analysis of a large cohort study of head-injured children in the pediatric emergency care applied research network. Pediatr Emerg Care 2015 (Epub ahead of print)
15. Marnewick J, Dansey R, Morreau P, Hamill J: Television tip-overs: The Starship Children's Hospital experience and literature review. Injury 42(5): 534-538, 2011

16. Mills J, Grushka J, Butterworth S: Television-related injuries in children-the British Columbia experience. J Pediatr Surg 47: 991-995, 2012

17. Muniz AE: Craniofacial injuries from television tip-over. Pediatr Emerg Care 28(1): 52-54, 2012

18. Murray KJ, Griffin R, Rue LW 3rd, McGwin G Jr: Recent trends in television tip over-related injuries among children aged 0-9 years. Inj Prev 15(4): 240-243, 2009

19. Ota FS, Maxson RT, Okada PJ: Childhood injuries caused by falling televisions. Acad Emerg Med 13: 700-703, 2006

20. Platt MS, Stanley C: TV Tip-Over Morbidity and Mortality in Children. J Forensic Sci 56(5):1364-1367, 2011

21. Rutkoski JD, Sippey M, Gaines BA: Traumatic television tipovers in the pediatric patient population. J Surg Res 166: 199-204, 2011

22. Samson SKG, Nair PR, Baldia M, Mathew J: Television tipover head injuries in children. Neurol India 58:752-755, 2010

23. Scheidler MG, Shultz BL, Schall L, Vyas A, Barksdale EM: Falling televisions: The hidden danger for children. J Pediatr Surg 37:572-575, 2002 